\title{
The Influence of Work Facilities on Employee Performance at the Regional Financial Management Agency Secretariat Section of South Sulawesi Province
}

\author{
Nurul Jihan Pratiwi, Jamaluddin, Risma Niswaty, Rudi Salam \\ Universitas Negeri Makassar \\ Email: rudisalam@unm.ac.id
}

(Received: March-2019; revised: April -2019; published: June-2019)

\begin{abstract}
Adequate work facilities with suitable conditions that are well maintained and will help smooth the work process in an organization. This study aims to determine the use of work facilities, on the performance of employees in the section of the Regional Financial Management Agency Secretariat of South Sulawesi Province. Therefore, to achieve these objectives researchers used data collection techniques with observation, questionnaires, and documentation with a population of 35 people. While the data analysis techniques used are descriptive statistical analysis using percentages and for inferential statistical analysis techniques using data normality tests, product moment correlation analysis, and simple linear regression analysis. The results of the study indicate that the work facilities in the section of the South Sulawesi Provincial Financial Management Agency Secretariat are in a good category, in terms of indicators: machinery and equipment, infrastructure, work equipment, land, and buildings. For the quality of employee performance in the section of the South Sulawesi Provincial Financial Management Agency Secretariat in a good category, which is viewed from: quality, quantity, timeliness, effectiveness, and independence. Based on the product moment correlation test analysis, there is a positive and significant influence on the use of work facilities on the performance of employees in the section of the Regional Financial Management Agency of South Sulawesi Province at $17.00 \%$, stated to be accepted with a moderate level of influence. From the results of simple linear regression analysis shows that there is an influence of work facilities on employee performance in the section of the Regional Financial Management Agency Secretariat of South Sulawesi Province.
\end{abstract}

Keywords: Work facilities; performance; employees

\section{INTRODUCTION}

Employee performance is a factor in determining the success of achieving goals because employee organization is a factor that can realize effectiveness and efficiency in carrying out tasks (Baharuddin, Asma, \& Niswaty, 2017; Norani, Amirullah, \& Darwis, 2015; Samad \& Jamaluddin, 2016). Work facilities provided by government offices are facilities and infrastructure to facilitate work (Haynes, 2008a; O’Neill, 2010). Adequate work facilities with suitable conditions that are well maintained and will help smooth the work process in an organization. Providing complete facilities is also used as one of the drivers for work (Haynes, 2008b; Preiser, 1995). An employee who has a high and good performance (results of work or work produced) can support the achievement of goals and objectives set by government organizations. Work facilities in principle focus on office or company work, which helps serve

Copyright (C) 2018 Universitas Negeri Makassar. This is an open access article under the CC BY license (http://creativecommons.org/licenses/by/4.0/) 


\author{
36 Jurnal Administrare: Jurnal Pemikiran Ilmiah dan Pendidikan Administrasi Perkantoran \\ Volume 6 Number 1 January-June 2019. Pages 35-44
}

various activities or smooth work. To achieve these objectives, work facilities are needed. Everything that becomes a supporting facility in various corporate activities in the form of physical and can be used in the normal activities of a company can be called a work facility. This work facility has benefits in the future and the age or useful life is relatively permanent. Work facilities as a tool or means to help employees more easily complete their work and employees will work more productively (Robertson, 2000; Roelofsen, 2002). An employee or worker cannot do the work assigned to him without a work tool. The better the work facilities, the higher the level of employee performance at work. Simply put, performance can be interpreted as the work of an employee, regardless of the results, not interpreted well or badly, or the high and low results of one's work. Work facilities are related to the work environment, because the work environment is also a work facility, with the existence of a comfortable work environment, employees can carry out work properly. Work facilities are supporting facilities in corporate activities in the form of physical and used in normal corporate activities, have a relatively permanent useful life period and provide benefits for the future (Asmanurhidayani, Saggaf, \& Salam, 2018; Daraba, Subianto, \& Salam, 2018; Farida, 2017).

Work facilities are a means or vehicle or tool to facilitate the activities of the company and also for the welfare of employees so that employees can carry out their work properly. Prawiro as quoted by sinambella argues that "performance is the result of work that can be achieved by a person or group of people in an organization, in accordance with their respective authority and responsibilities, in order to achieve the objectives of the organization in question, not violating the law and in accordance with moral and ethics ". Khaerul Umam argues that "performance is something commonly used to monitor the work productivity of human resources, both oriented to production, goods, and services. likewise, the realization of a proud performance is also an intrinsic reward ". This will continue in the form of the next performance, and so on. In order to achieve professional performance, things like volunteerism, personal development, development of mutually beneficial cooperation, and full participation need to be developed.

\title{
METHOD
}

This research is a quantitative research to measure the effect of work facility variables on employee performance variables. The population in this study were all employees at the Secretariat Section, namely as many as 35 respondents. In this study the authors did not use sample techniques and took all the existing populations or in other words this study used population research. Data collection techniques used are observation, questionnaires, interviews and documentation techniques. The data analysis technique used is descriptive statistical analysis and inferential statistical analysis. Descriptive statistical analysis consisted of percentages, averages and standard deviations. While inferential stastic analysis consists of data normality test, moment product correlation and simple linear regression analysis.

\section{RESULT AND DISCUSSION}

\section{Work Facilities}

The data presented in this study are data obtained from the questionnaire scores that have been given to 35 employees who became the study population intended to determine the effect 
of work facilities on employee performance in the section of the Regional Financial Management Agency of South Sulawesi Province. In the variables of work facilities there are 5 (five) indicators, namely: 1) Machinery and Equipment, 2) Infrastructure, 3) Work Equipment, 4) Land, and 5) Buildings. For more details, it will be presented in table 1.

Table 1.

Overview of Work Facilities

\begin{tabular}{clcccc}
\hline No. & \multicolumn{1}{c}{ Indicator } & n & N & \% & Kategori \\
\hline 1 & Machinery and Equipment & 981 & 1225 & 80.08 & Well \\
2 & Infrastructure & 418 & 525 & 79.62 & Well \\
3 & Work equipment & 566 & 700 & 80.86 & Well \\
4 & Soil & 428 & 525 & 81.52 & Very good \\
5 & Building & 439 & 525 & 83.62 & Very good \\
\hline Total & & 2832 & 3500 & 80.91 & Well \\
\hline
\end{tabular}

Source: Results of Questionnaire, 2019

The results of data analysis in table 1, can be seen building indicators show that the building is at the highest percentage of $83.62 \%$ and is in the very good category, due to the condition of the building / building that is well maintained, feasible, and strong / strong. Land, is in a very good category with a percentage of $81.52 \%$. Work equipment is in a good category with a percentage value of $80.86 \%$. The machines and equipment are in a good category with a percentage value of $80.08 \%$, and infrastructure is in a good category with a percentage value of $79.62 \%$. Based on the results of the analysis in the table above, the work facility variable (X) is in a very good category with a percentage level of $85.88 \%$. The analysis of the average variable work facilities (X) can be seen in table 2 .

Table 2.

Descriptive Analysis Results

\begin{tabular}{|c|c|c|}
\hline $\mathrm{N}$ & Valid & 35 \\
\hline & Missing & 6 \\
\hline $\mathrm{Me}$ & & 81.77 \\
\hline & & 81.00 \\
\hline & & 80 \\
\hline & iation & 3.949 \\
\hline & & 74 \\
\hline & & 90 \\
\hline Sur & & 2862 \\
\hline
\end{tabular}

Source: Results of Statistical Analysis Through SPSS.16 Program

Based on the results of the analysis of the mean and standard deviation on work facility variables $(\mathrm{X})$ in table 2 , shows that the average value obtained from respondents' answer score is 81.77 , then the average 81.77 is in the very strong category with standards deviation 3,949 . 


\section{Jurnal Administrare: Jurnal Pemikiran Ilmiah dan Pendidikan Administrasi Perkantoran Volume 6 Number 1 January-June 2019. Pages 35-44}

The results of the mean and standard deviation in the table above are reviewed from the indicators of machinery and equipment, infrastructure, work equipment, land and buildings.

\section{Employee Performance}

To find out the description of employee performance in the section of the Regional Financial Management Agency Secretariat of South Sulawesi Province. The data presented in this study are data obtained from the results of scores from the questionnaire that have been filled in by the respondents. On employee performance variables there are 5 (five) indicators, namely: 1) Quality, 2) Quantity, 3) Timeliness, 4) Effectiveness, and 5) Independence. For more details, it is presented in Table 3.

\section{Table 3.}

Overview of Employee Performance

\begin{tabular}{clcccl}
\hline No. & Indicator & n & N & \% & Category \\
\hline 1 & Quality & 908 & 1225 & 74.12 & Well \\
2 & Quantity & 387 & 525 & 73.71 & Well \\
3 & Punctuality & 377 & 525 & 71.81 & Well \\
4 & Effectiveness & 366 & 525 & 69.71 & Pretty good \\
5 & Independence & 393 & 525 & 74.86 & Well \\
\hline Total & & $\mathbf{2 4 3 1}$ & $\mathbf{3 3 2 5}$ & $\mathbf{7 3 . 1 1}$ & Well \\
\hline
\end{tabular}

Source: Results of Questionnaire, 2019

The results of data analysis in table 3, the employee performance variable shows that, the independence indicator gets the highest percentage of $74.86 \%$ with a good category level, because employees can be responsible, work on and complete the work that has been given. Quality gets a percentage of $74.12 \%$ with a good category level. Then the quantity obtained a percentage of $73.71 \%$ with the level of good category, the timeliness of obtaining a percentage of $71.81 \%$ with a level of good category, and the last indicator is the effectiveness of getting a percentage of $69.71 \%$ with a fairly good category level. Based on the results of data analysis in table 4 above, the variable employee performance (Y) obtained a percentage of $73.11 \%$ with a good category level. The results of the average analysis and standard deviation can be seen in table 4.

Table 4.

Results of Average Analysis and Standard Deviation of Variable Employee Performance

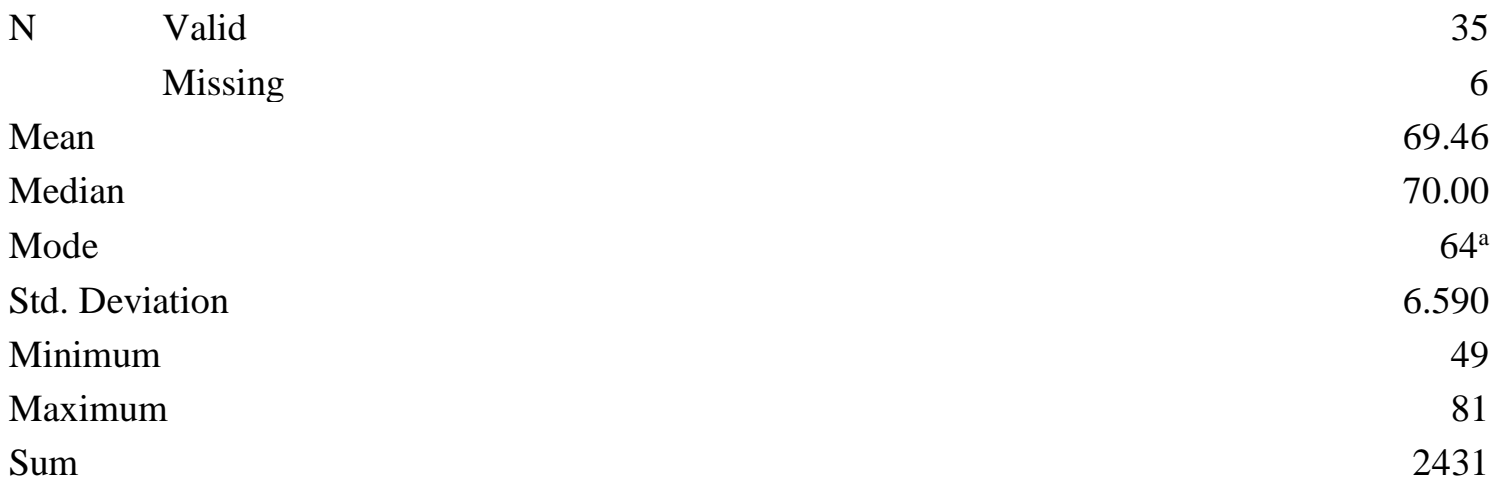

Source: Results of Statistical Analysis Through SPSS.16 Program 
Based on the results of the average analysis and standard deviation on employee performance variables ( $\mathrm{Y}$ ) in table 4 , it shows that the average value obtained from the respondent's answer score is 69.46 and if it is matched with the measurement standards in chapter III page 29, then the average 69.46 is in the strong category with a standard deviation of 6,590 . The results of the average value and standard deviation in the table are reviewed from the indicators of quality, quantity, timeliness, effectiveness, and independence.

\section{Data Normality Test}

Before further analysis, it is first necessary to know whether the data obtained has met the requirements for using statistics used in testing the hypothesis. Testing the analysis requirements for the use of statistics is the data obtained at least normally distributed. The normality test of the data serves to determine the normality of data regarding work facilities and employee performance in the section of the Regional Financial Management Agency of South Sulawesi Province. The test used in this study compares the Chi Square calculation and Chi Square tables. Provisions for Chi Squares count are smaller or equal to Chi Square tables (X2h $\leq \mathrm{X} 2 \mathrm{t}$ ), then the data obtained is declared to be normally distributed, if the opposite occurs then the data is said to be abnormal. The results of normality of data can be seen in table 5 .

\section{Tabel 5.}

Normality Test Data Results with Sig.5\%

\begin{tabular}{lcccc}
\hline \multicolumn{1}{c}{ Variable } & $\mathbf{X}^{2}$ Count & $\mathbf{X}_{\text {table }}$ & df & Information \\
\hline Work Facilities & 12.600 & 22.632 & 13 & Normal \\
Employee Performance & 7.600 & 31.410 & 20 & Normal \\
\hline Souc
\end{tabular}

Source: Results of Statistical Analysis Through SPSS.16 Program

Based on table 5, it can be seen the results of the data normality test work, that the work facility variable $(\mathrm{X})$ is declared to be normally crystallized because it meets the requirements of $\mathrm{X} 2$ count $(12,600)$ smaller $(\leq)$ than X2 table with Df 13 of 22,632. Similarly, the employee performance variable $(\mathrm{Y})$ is stated to be normally distributed because it also fulfills the $\mathrm{X} 2$ count $(7,600)$ requirement smaller $(\leq)$ than X2 table with Df 20 of 31,410 .

\section{Product Moment Correlation Analysis}

The moment product correlation test is intended to determine whether there is a relationship between work facilities and employee performance in the Regional Financial Management Agency Secretariat of South Sulawesi Province. To find out how much influence the work facilities have on employee performance, can be seen in table 6:

Table 6.

Product Moment Correlation Test Results with Significant 5\%

Model R R Square Adjusted R Square Std. Error of the Estimate

\begin{tabular}{lllll}
\hline 1 & $.412^{\mathrm{a}}$ & .170 & .145 & 3.652
\end{tabular}




\section{Jurnal Administrare: Jurnal Pemikiran Ilmiah dan Pendidikan Administrasi Perkantoran Volume 6 Number 1 January-June 2019. Pages 35-44}

\section{Source: Results of Statistical Analysis Through SPSS.16 Program}

Based on the results of the moment product correlation calculation obtained rcount of 0.412 , if interpreted in the opinion of Sugiyono (2012) then 0.412 is in the interval $0.40-0.599$ with a moderate relationship level. To test the significant relationship, is there a relationship found that applies to the entire population. Whether or not there is a significant correlation of the results, then compared $\mathrm{r}$ count with rtable with a significant level of 5\% and respondent $(\mathrm{N})$ $=35$, then obtained rtable of 0.334 .

\section{Simple Linear Regression Analysis}

To find out whether there is an influence between work facilities on employee performance in the section of the Regional Financial Management Agency Secretariat of South Sulawesi Province. Then used a simple linear regression analysis that can be seen in table 6, From the moment product correlation test results it can be stated that there is a significant relationship between work facilities on employee performance in the section of the Regional Financial Management Agency of South Sulawesi Province, due to $r_{\text {count }}(0.412)$ than $r_{\text {Table }}$ (0.334) then $\mathrm{H} 0$ is rejected and $\mathrm{H} 1$ is accepted. With the determination coefficient obtained $\mathrm{r} 2=$ 0.170 or $17.00 \%$. Which means that employee performance is determined by work facilities of $17.00 \%$ while the remainder is determined by other factors not examined in this study at $83.00 \%$. Next to find out the regression formula is presented in table 7 :

Table 7.

Results of Simple Linear Regression Analysis

\begin{tabular}{lccccc}
\hline \multicolumn{1}{c}{ Variable } & $\boldsymbol{\beta}$ & $\mathbf{F}_{\text {count }}$ & Sig. & $\mathbf{t}_{\text {count }}$ & Sig. \\
\hline Constants & 13.214 & & & 9.747 & 0.546 \\
Work Facilities & 0.688 & 6.752 & 0.014 & 2.598 & 0.014 \\
\hline
\end{tabular}

Source: Results of Statistical Analysis Through SPSS.16 Program

Based on table 7 it is known that the calculation of a simple linear regression equation is obtained by the value $\alpha=13.214$ and $\beta=0.688$ so that the regression equation is $\hat{Y}=13.214+$ 0.688 . From the calculation of the F-Test obtained $F_{\text {count }}$ of 6.752 and Ftable $(0.05: 1: 33)$ of 4.14 which means that Fcount is greater than $F_{\text {table. }}$ Due to $F_{\text {count }}>$ so that it can be said that there is an influence of work facilities on employee performance in the part of the Regional Financial Management Agency Secretariat of South Sulawesi Province.

\section{Pembahasan}

\section{a. Work Facilities}

Work facilities are supporting facilities in corporate activities in the form of physical and used in normal company activities, have a relatively permanent useful life period and provide benefits for the future. Riva'i argues that, work facilities are anything that can facilitate efforts and improve work in order to achieve a goal. The results showed that the level of use of work facilities in the part of the Regional Financial Management Agency Secretariat of South Sulawesi Province was in the good category 
The machine and equipment are all equipment used to support the work processes that exist in the company. In this aspect of the indicator, it shows that work facilities in the form of machinery and equipment are in good category. Where the machinery and equipment can support the achievement of work objectives with conditions that are feasible, used for work activities, easy to use, and speed up the work process, and the placement is arranged properly.

Infrastructure, namely supporting facilities used to facilitate company activities, including bridges, roads, fences and others. Based on the results of the research data on this indicator, the infrastructure is in the good category. Where infrastructure can assist in the work process, the condition of the infrastructure that can function properly, and the condition of the infrastructure is safe to use

Work equipment that is a facility that supports activity activities in offices, such as office furniture (tables, chairs, cabinets, etc.). Electronic equipment in the form (computers, photo copy machines, printers, and other calculating devices). In this aspect of the indicator shows that work equipment is in the good category. Where office supplies such as computers, photocopying machines, paper shredders, printers, tables, chairs, and cabinets are available in every workspace and can function properly.

Land is an asset that extends widely both used in place of building, or an empty land used for company activities. Based on the results of research data on this indicator, land is in a very good category. Where land is well maintained, free from wild plants, and often used for work activities.

Buildings are facilities that support company activities such as warehousing. Based on the results of research data on this indicator, buildings are in a very good category. Where the condition of the building for work activities is feasible to use with well-maintained conditions, as well as the condition of a sturdy building.

The use of work facilities in the section of the South Sulawesi Provincial Financial Management Agency Secretariat can be carried out well, this is inseparable from the way the leadership utilizes the use of available work facilities and presents work facilities that are not yet available. This is also inseparable from the leadership efforts to improve employee performance with efforts to conduct supervision, guidance, and training. Basically the use of work facilities has a very important role, the more or varied the work facilities used, the employees will be motivated at work. The higher the quality of work facilities used, the better employee performance will be.

\section{b. Employee Performance}

Employee performance is the work result in quality and quantity achieved by an employee in carrying out its functions in accordance with the responsibilities given to him. Prawiro as quoted by sinambella argues that "performance is the result of work that can be achieved by a person or group of people in an organization, in accordance with their respective authority and responsibilities, in order to achieve the objectives of the organization in question, not violate the law and in accordance with moral and ethics ". The results of the study on employee performance variables in the section of the Regional Financial Management Agency of South Sulawesi Province are in the good category

The quality of work is measured by employee perceptions of the quality of work produced and the task's perfection of employees' skills and abilities. Based on the results of the research data on this indicator, the quality is in the good category. Used by competent 


\section{Jurnal Administrare: Jurnal Pemikiran Ilmiah dan Pendidikan Administrasi Perkantoran Volume 6 Number 1 January-June 2019. Pages 35-44}

employees and masters of the tasks assigned, can work with other employees, experienced in the field of tasks assigned, can take decisions or resolve their own problems, prioritize the interests of the office, dare to bear risks, and be able to complete the tasks and work provided as well as possible.

Quantity is the amount generated in terms of units, the number of cycles of activity completed. Based on the results of the research data on this indicator, the quantity is in the good category. Due to the number of employees working in accordance with a predetermined time and employees entering and returning from work according to the work schedule.

Timeliness is the level of an activity completed at the desired initial time, seen in terms of coordination with output results and maximizing the time available for other activities. Based on the results of the research data on this indicator, the timeliness is in the good category. Where employees can complete the work carefully and on time, can maximize time for other activities, and discipline in carrying out tasks and jobs.

Effectiveness is the level of use of organizational resources (energy, money, technology, raw materials) maximized in order to increase the yield of each unit in the use of resources. Based on the results of research data on this indicator, effectiveness is in a fairly good category where employees have skills in work, are able to compete positively, and can adapt to situations and work environments.

Independence is the level of someone's employee who will later be able to carry out his work function. Based on the results of the research data on this indicator, independence is in the good category. Where employees can be responsible for the work provided, and work on and complete the work with their own hard work. Good employee performance can also be carried out well if there is a good reciprocal relationship between employees and leaders in the work process.

\section{c. Effect of Work Facilities on Employee Performance}

Based on the results of testing the hypothesis between work facility variables on employee performance in the section of the Regional Financial Management Agency Secretariat of South Sulawesi Province, where the two variables have a significant relationship. This means that the hypothesis in this study "allegedly had the influence of work facilities on the performance of employees in the section of the Regional Financial Management Agency Secretariat of South Sulawesi Province" was declared acceptable with a moderate level of influence.

Sudarwan Danim stated that, companies should provide pleasant facilities for their employees, so if the office is able to provide these facilities, the office can increase the enthusiasm of the work of the employees so that their work can also be improved. The work facility is also a support for improving employee performance in the section of the Regional Financial Management Agency of South Sulawesi Province. This is inseparable from the importance of using work facilities as a means of facilitating the work process of employees. Thus, work facilities provided by offices such as machinery and equipment, infrastructure, work equipment, land, and buildings strongly support employees in their work because these facilities can help employees make it easier to complete their work optimally.

The use of work facilities will provide a good influence on employee performance, with the use of optimal work facilities will increasingly stimulate employee performance in work 
which will ultimately improve employee performance indirectly. With work facilities that have been prepared, the employees will feel comfortable in their work and can generate morale to get the results expected by the Regional Finance Management Board of South Sulawesi Province. It can be said that the use of work facilities namely machinery and equipment, infrastructure, work equipment, land, and buildings will have a positive effect on employee performance. Good work facilities are one of the important factors in improving employee performance. From the results of research conducted at the office of the Regional Financial Management Agency of South Sulawesi Province it can be concluded that work facilities are already very good, where the work of employees is greatly helped by the existence of suitable and adequate work facilities. The South Sulawesi Provincial Financial Management Agency has strived to further improve work facilities so that employee performance will improve.

\section{CONCLUSION}

Work Facilities (X) in the section of the South Sulawesi Provincial Financial Management Agency Secretariat are in the good category, in terms of indicators of machinery and equipment, infrastructure, work equipment, land, and buildings. Employee Performance $(Y)$ in the section of the South Sulawesi Provincial Financial Management Agency Secretariat is in a good category, this is reviewed in terms of indicators of quality, quantity, timeliness, effectiveness, and independence. There is a significant influence between work facilities on employee performance in the section of the Regional Financial Management Agency Secretariat of South Sulawesi Province.

\section{REFERENCES}

Asmanurhidayani, A., Saggaf, M. S., \& Salam, R. (2018). The Effect Of Cooperation On Quality Work At Family Planning Office And Family Welfare Office In Wajo Regency.

Baharuddin, A., Asma, A., \& Niswaty, R. (2017). Efektivitas Kinerja Pegawai di Kantor Kelurahan Lanrisang Kecamatan Lanrisang Kabupaten Pinrang. Jurnal Ad'ministrare, 4(1), 1-6.

Daraba, D., Subianto, A. B., \& Salam, R. (2018). An effort to Improve the Quality of Workers at the Makassar city Department of Employment Services. Jurnal Ilmiah Ilmu Administrasi Publik, 8(1), 21-26.

Farida, U. (2017). Analysis of Empowerment Program that was Implemented in Mamuju Regency East Sulawesi Indonesia. 149(Icest), 19-21.

Haynes, B. P. (2008a). An evaluation of the impact of the office environment on productivity. Facilities. https://doi.org/10.1108/02632770810864970

Haynes, B. P. (2008b). The impact of office layout on productivity. Journal of Facilities Management. https://doi.org/10.1108/14725960810885961

Norani, M., Amirullah, A. H., \& Darwis, M. (2015). Efektivitas Kinerja Pegawai Pada Kantor Kementerian Agama Kota Makassar. Jurnal Office, 1(1), 1-7.

O’Neill, M. J. (2010). A model of environmental control and effective work. Facilities. 
44 | Jurnal Administrare: Jurnal Pemikiran Ilmiah dan Pendidikan Administrasi Perkantoran Volume 6 Number 1 January-June 2019. Pages 35-44

https://doi.org/10.1108/02632771011023104

Preiser, W. F. E. (1995). Evaluation: How To Make Buildings Work Better. Facilities. https://doi.org/https://doi.org/10.1108/02632779510097787

Robertson, K. (2000). Work transformation: Integrating people, space and technology. Facilities. https://doi.org/10.1108/02632770010349600

Roelofsen, P. (2002). The impact of office environments on employee performance: The design of the workplace as a strategy for productivity enhancement. Journal of Facilities Management. https://doi.org/10.1108/14725960310807944

Samad, A., \& Jamaluddin, J. (2016). Efektivitas Pengembangan Sumber Daya Pegawai Di SMK YPLP PGRI 1 Makassar. Jurnal Office, 2(2), 195-202. 